\title{
A study of association between serum zinc and HbA1c in type2 diabetic patients in a tertiary care hospital in Puducherry, Tamilnadu
}

\author{
Dhanoushyaa Seetharaman', Muraliswaran Perumal'2, Priyatharshini Mohan³, \\ Prabu Gnanasekaran ${ }^{4}$, Indhumathi Venkatesan ${ }^{5}$ \\ ${ }^{1,5}$ MBBS III year Student, Sri Venkateshwaraa Medical College Hospital and Research Centre, Puducherry, India \\ ${ }^{2}$ Professor, ${ }^{3}$ Associate Professor, Department of Biochemistry, Sri Venkateshwaraa Medical College Hospital and \\ Research Centre, Puducherry, India, ${ }^{4}$ Professor, Department of General Medicine, Sri Venkateshwaraa Medical \\ College Hospital and Research Centre, Puducherry, India
}

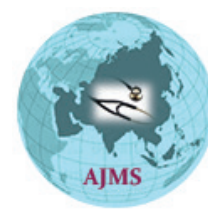

A B S TR A C T

Background: Diabetes currently affects more than 66.8 million people in India which has become a major health care problem, representing the largest number of any country in the world. Reduced concomitant intake of Zinc studies proved to be associated with risk of increased $\mathrm{HbA} 1 \mathrm{c}$ percentage in individuals with Type 2 Diabetes patients. Aims and Objective: The current study was designed to assess serum Zinc level in Type 2 Diabetes patients and to find out the correlation between serum Zinc and $\mathrm{HbA} 1 \mathrm{c}$ level in Type 2 Diabetic patients. Materials and Methods: One hundred patients were included in the study and they were divided into two groups like Group I (50 patients): Type 2 Diabetic patients with $\mathrm{HbA} 1 \mathrm{c}$ more than 7 percent. Group II (50 patients): Type 2 Diabetic patients with $\mathrm{HbA} 1 \mathrm{c}$ less than 7 percent (50). Estimation of blood glucose (Fasting and post prandial), Glycated haemoglobin ( $\mathrm{HbA} 1 \mathrm{c})$ and serum Zinc was done. Statistical Analysis: The data is collected, recorded and analyzed statistically to determine the significance of different parameters by using SPSS package for windows version23.0. Results: The mean value of serum zinc was lower in the diabetic group whose HbA1c more than 7 ( $p$ value -0.001 ) when compared to the diabetic group whose $\mathrm{HbA} 1 \mathrm{c}$ less than 7. Conclusion: Estimating the level of serum zinc becomes important to know the status of insulin in diabetic patients and correlating the levels of $\mathrm{HbA} 1 \mathrm{c}$ and Serum zinc in Type $2 \mathrm{DM}$ patients, can monitor the levels of glycemic control and prevent the risk of development of complications.

\section{Access this article online}

Website:

http://nepjol.info/index.php/AJMS DOI: 10.3126/ajms.v12i8.36411 E-ISSN: 2091-0576 P-ISSN: 2467-9100

Copyright (c) 2021 Asian Journal of Medical Sciences

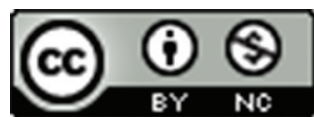

This work is licensed under a Creative Commons Attribution-NonCommercial 4.0 International License.

Key words: Serum Zinc; HbA1c; Diabetes; Complications

\section{INTRODUCTION}

Diabetes currently affects more than 66.8 million people in India has become a major health care problem with largest number of cases in the world. ${ }^{1}$ Trace elements are essential for the metabolism of proteins, carbohydrates and lipids. In 1938, Scott and Fisher first reported that amount of zinc $(\mathrm{Zn})$ in pancreatic tissue of cadavers of diabetic patients was approximately $50 \%$ of that in nondiabetics, suggesting an association between zinc and Diabetes mellitus. ${ }^{2}$ Symptoms of diabetes include excessive urination, increased thirst and hunger, weight loss, slow wound healing, numbness in feet. ${ }^{3}$ It may cause severe health complications if not treated on time including microvascular complications (Diabetic nephropathy, neuropathy, retinopathy), Macrovascular complications (Atherosclerosis, Peripheral Vascular Diseases, Ischemic Heart Disease, Cerebrovascular Diseases), and other miscellaneous complications (Diabetic cardiomyopathy). ${ }^{4}$ Studies suggests that reduced concomitant intake of Zinc studies might be associated with increased risk of elevated $\mathrm{HbA} 1 \mathrm{c}$ in individuals with Type 2 Diabetes. ${ }^{5}$ Postmenopausal women are especially vulnerable to zinc deficiency, due to serious hormonal changes during that 
time. ${ }^{6}$ Zinc is a trace element that acts as a co-factor for synthesis, storage, stability and secretion of insulin by pancreas. In addition to this, it also accounts for the conformation integrity of insulin in its hexameric crystalline form. ${ }^{7}$ Insulin present in beta-cells of the pancreas as a hexamer of six insulin and two zinc molecules. Its crystallization occurs under specific conditions in secretory granules, in which both insulin and zinc exist in high concentration and acidic $\mathrm{pH}$ is maintained. ${ }^{8} \mathrm{Zinc}$ is involved in the regulation of insulin receptor initiated signal transduction mechanism and insulin receptor synthesis. Furthermore, it acts as a cofactor of intracellular enzymes involved in protein, lipid, glucose metabolism and is an integral component of several antioxidant enzymes. ${ }^{9}$ Zinc has an important role in the glucose utilization by muscle and fat cells. ${ }^{10}$ Metallothioneins (MTs), zinc importers (ZIP, SLC39A), and zinc exporters (ZnT, SLC30A) are proteins that regulate cellular zinc homeostasis. ${ }^{11} \mathrm{ZnT} 8$ plays a key role in the accumulation of zinc within insulin secretory granules. ${ }^{12}$ Study suggest that several key glycemic indicators are significantly reduced in diabetic patients on zinc supplementation and the findings support the notion that zinc supplementation has a clinical potential for preventing or treating diabetes. ${ }^{13}$ Inadequate Zinc distribution may affect the onset of diabetes by regulating various critical biological events. ${ }^{14}$ Observations during zinc deficiency indicate that the absence of this trace element most severely affects the immune response indicating their role in immunity. ${ }^{15}$ Several beneficial effects of Zinc supplementations in patients with diabetes mellitus, namely improved glycemic control, lipid parameters, antioxidant status has been identified. Additionally, it also causes significant reduction in FBG, PPBG and HbA1c in patients with Type-2 diabetes due to its insulin mimetic and hypoglycemic properties. ${ }^{16} \mathrm{With}$ the all above relationship of zinc with insulin, the aim of the present study is to study the correlation of serum zinc levels with $\mathrm{HbA} 1 \mathrm{c}$ in type $2 \mathrm{DM}$.

This is a hospital based case control study conducted on Type 2 Diabetes mellitus patients attending the General Medicine and Diabetology clinic of Sri Venkateshwaraa Medical College Hospital, Ariyur, Puducherry. The duration of study was 6 months from January 2019 to August 2019. A convenient sample of $100 \mathrm{old}$ and new patients of Type 2 Diabetes Mellitus were included in the study consisting of Group I (50 patients): Type 2 Diabetic patients with HbA1c more than 7 percent and Group II (50 patients): Type 2 Diabetic patients with HbA1c less than7 percent after taking an informed consent. Patients with history of hepatic diseases, renal diseases, alcoholism or critically ill patients or those on mineral supplementation were excluded from the study. A proforma containing the general information of the patient like name, age, sex, socioeconomic status, and relevant history pertaining to diabetes mellitus like duration of the disease, complications if any, treatment taken, etc. was asked from the patient. Institutional Ethical Committee clearance was obtained before the commencement of the study.

During sample collection, $5 \mathrm{ml}$ of venous blood was drawn under aseptic precautions in red capped vacutainers, grey capped vacutainers and purple capped vacutainers. Then, serum was separated by centrifugation and was used for analysis of serum zinc by colorimetric method based Nitro-Paps method. Plasma was used for analysis of blood glucose by GOD-POD Method and whole blood for HbA1c estimation based on Immunoturbidity method.

\section{Statistical analysis}

The data was collected, recorded and analyzed statistically to determine the significance of different parameters by using SPSS package for windows version 23.0.

\section{RESULTS}

A case control study was conducted with 100 type 2 Diabetic patients who were divided into 2 groups consisting of 56 Type 2 Diabetic patients with HbA1c more than 7 percent in Group I and 44 Type 2 Diabetic patients with HbA1c less than 7percent in Group II (Table 1).

Table 2 shows that the mean values of serum zinc and HbA1c levels. Mean serum zinc was lower in the diabetic group whose HbA1c more than 7 ( $p$ value -0.000 ) when compared to the diabetic group whose HbA1c less than 7.

Table 3 shows Serum Zinc has a strong negative correlation $(\mathrm{r}=-0.391)$ with HbA1 $\mathrm{c}$ in the Type 2 diabetic patients with HbA1c $>7(p=0.001)$. Scatter diagram showing correlation between HbA1c and serum zinc is shown in Figure 1.

\section{DISCUSSION}

The present study was conducted with the aim to correlate the serum zinc levels with the glycated haemoglobin in type

\begin{tabular}{|c|c|c|}
\hline & $\begin{array}{l}\text { T2 DM patients with } \\
\text { HbA1c }>7(n=56)\end{array}$ & $\begin{array}{l}\text { T2 DM patients with } \\
\text { HbA1c }<7(n=44)\end{array}$ \\
\hline Age & $49 \pm 14.5$ & $53 \pm 13.7$ \\
\hline \multirow[t]{2}{*}{ Sex } & $M=35$ & $M=30$ \\
\hline & $F=21$ & $F=14$ \\
\hline Blood sugar & $\begin{aligned} \mathrm{FBS} & =175 \pm 21.4 \\
\mathrm{PPBS} & =258 \pm 44.1\end{aligned}$ & $\begin{array}{c}\mathrm{FBS}=118 \pm 19.0 \\
\mathrm{PPBS}=185 \pm 18.4\end{array}$ \\
\hline $\mathrm{HbA1c}$ & $10.5 \pm 2.5$ & $5.9 \pm 0.59$ \\
\hline Serum Zinc & $46.06+17.28$ & $62.94+16.34$ \\
\hline
\end{tabular}


2 diabetic patients. The diabetic patients were divided into 2 groups. Group I comprised of type 2 diabetic patients with $\mathrm{HbA} 1 \mathrm{c}$ level more than 7 and consisted of 56 diabetic patients in number with 35 male and 21 female patients. Group II consisted of type 2 diabetic patients whose HbA1c was less than 7 with 44 patients -30 male and 14 female patients. The mean values of serum zinc were significantly higher in Group II as compared to Group I ( $p$ value 0.001 ). The 2 groups were correlated for glycated haemoglobin and serum zinc level. It indicated a statistically significant negative correlation $(r$ value $=-0.338$. These findings were in accordance with the study done by Santosh K. Naik et al, in 2019 where there was a significant negative correlation between serum zinc and HbA1c. ${ }^{17}$ In a study done by Jyothirmayi B et al., ${ }^{18}$ they identified significant decrease in serum concentrations of Zinc in study group (type $2 \mathrm{DM}$ ) when compared to control group consisting of healthy individuals. Similarly in a study done by Ramesh

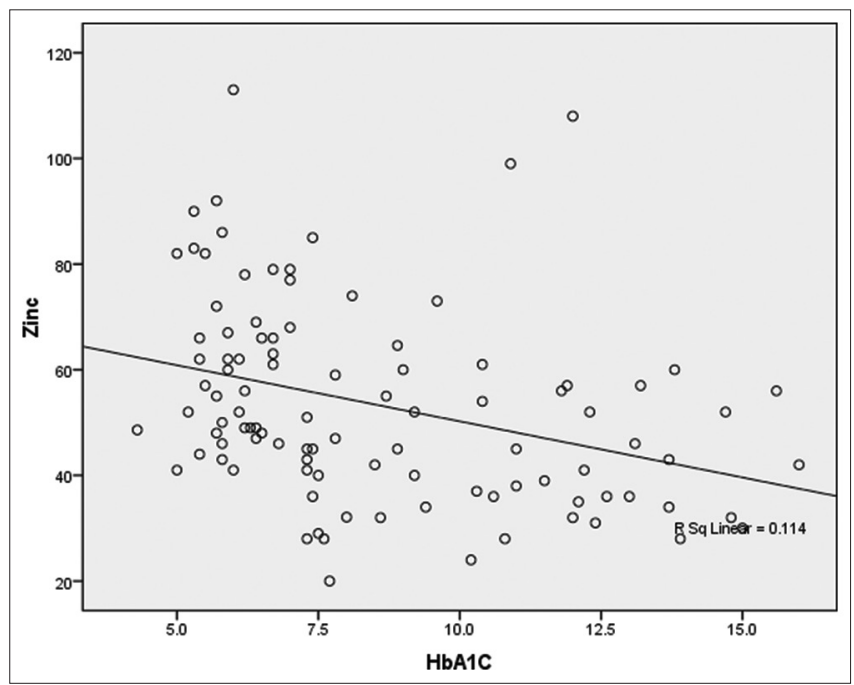

Figure 1: Scatter diagram showing correlation between $\mathrm{HbA} 1 \mathrm{c}$ and serum zinc

Table 2: Compare the mean values of $\mathrm{HbA1c}$ and Serum Zinc between the 2 groups

\begin{tabular}{lccc} 
& $\begin{array}{c}\text { T2 DM patients } \\
\text { with HbA1c }>\text { 7 } \\
(\mathbf{n}=\mathbf{5 6})\end{array}$ & $\begin{array}{c}\text { T2 DM patients } \\
\text { with HbA1c }<7 \\
(\mathbf{n}=\mathbf{4 4})\end{array}$ & P value \\
\hline HbA1c & $10.5 \pm 2.5$ & $5.9 \pm 0.59$ & $0.001^{* *}$ \\
Serum zinc & $46.06+17.28$ & $62.94+16.34$ & $0.001^{* *}$ \\
\hline ** - highly significant $(\mathrm{p}$ value $-<0.001)$ & &
\end{tabular}

\begin{tabular}{|c|c|c|}
\hline & Seru & \\
\hline $\mathrm{HbA} 1 \mathrm{c}$ & $\begin{array}{l}\text { Pearson's correlation } \\
\text { Sig } 2 \text { tailed } \\
\text { N }\end{array}$ & $\begin{array}{c}-0.338^{* *} \\
0.001 \\
100\end{array}$ \\
\hline
\end{tabular}

Dasarathan et al., in $2017^{19}$ also suggested that zinc has strong negative correlation with HbA1c. In a study done by Sunthari K et al. ${ }^{20}$ in South India concluded that there is significant reduction of serum $\mathrm{Zn}$ in Type 2 Diabetes Mellitus patients in relationship with high HbA1c. In a study done by Sunita Pujar et al., ${ }^{21}$ demonstrated a negative correlation in the serum levels of zinc and magnesium with HbA1c in diabetics.

Zinc, an essential element is useful in the synthesis, storage and secretion of insulin. Estimating the level of serum zinc becomes important to know the status of insulin resistance in diabetic patients.. Zinc supplementation to the diabetic patients can help in better glycemic control and prevent diabetes related complications as well as bone ailments.

\section{ACKNOWLEDGEMENTS}

The authors take this opportunity to thank Department of Medicine for their whole-hearted support for this study and we thank ICMR for selecting our study for STS ICMR.

\section{REFERENCES}

1. Joshi SR. Diabetes care in India. Ann Global Health. 2015; 81(6):830-838

https://doi.org/10.1016/j.aogh.2016.01.002

2. Scott DA and Fisher AM. The insulin and the zinc content of normal and diabetic pancreas. J Clin Invest. 1938; 17(6):725-728. https://doi.org/10.1172/JCl101000

3. World Health Organisation. Diabetes fact sheet, 2013.

4. Papatheodorou K, Papanas N, Banach M, Papazoglou D and Edmonds M. Complictions of Diabetes 2016. J Diabetes Res. 2016; 2016:6989453.

https://doi.org/10.1155/2016/6989453

5. Brandao Lima PN, de Carvalho GB, Fonseca Santos RK, da Cruz Santos B, Dias-Vasconcelos NL, de Sousa Rocha V, et al. Intakes of Zinc, Potassium, Calcium, and Magnesium of Individuals with Type-2 Diabetes Mellitus and the Relationship with Glycemic Control. Nutrients. 2018; 10(12):1948.

https://doi.org/10.3390/nu10121948

6. Researchers from RUDN University and P.G Demidov Yaroslavl State University. Scientists prove the role of zinc in Type 2 diabetes mellitus. Journal of Trace Elements in Medicine and Biology.2017.

7. Dunn MF. Zinc-ligand interactions modulate assembly and stability of the insulin hexamer -A review. Biometals. 2005; 18(4): 295-303. https://doi.org/10.1007/s10534-005-3685-y

8. Kimura $T$ and Kambe T. The Functions of Metallothionein and ZIP and ZnT Transporters: An Overview and Perspective. Int J Mol Sci. 2016; 17(3):336.

https://doi.org/10.3390/ijms17030336

9. Anderson RA, Roussel AM, Zouari N, Mahjoub S, Matheau JM and Kerkeni A. Potential antioxidant effects of zinc and chromium supplementation in people with type 2 diabetes mellitus. J Am Coll Nutr. 2001; 20(3): 212-218. 
https://doi.org/10.1080/07315724.2001.10719034

10. Cruz KJ, de Oliveira AR and Marreiro DN. Antioxidant role of zinc in diabetes mellitus. World J Diabetes. 2015; 6(2):333-337. https://doi.org/10.4239/wjd.v6.i2.333

11. Hara T, Takeda TA, Takagishi T, FukueK, Kambe T and Fukada T Physiological roles of zinc transporters: Molecular and genetic importance in zinc homeostasis. J Physiol Sci. 2017; 67(2): 283-301.

https://doi.org/10.1007/s12576-017-0521-4

12. Chimienti F, Devergnas S, Pattou F, Schuit F, Garcia-Cuenca, R, Vandewalle $B$, et al. In vivo expression and functional characterization of the zinc transporter ZnT8 in glucose-induced insulin secretion. J Cell Sci. 2006; 119(Pt 20): 4199-4206.

https://doi.org/10.1242/jcs.03164

13. Wang $X$, Wu W, Zheng $W$, Fang $X$, Chen $L$, Rink $L$, et al. Zinc supplementation improves glycemic control for diabetes prevention and management: a systemic review and metaanalysis of randomized controlled trials. The American Journal of Clinical Nutrition. 2019; 110(1): 76-90.

https://doi.org/10.1093/ajcn/nqz041

14. Fukunaka A and FujitaniY. Role of Zinc Homeostasis in the Pathogenesis of Diabetes and Obesity. Int J Mol Sci. 2018; 19(2).476.

https://doi.org/10.3390/ijms19020476

15. Haase $\mathrm{H}$ and Rink L. Multiple impacts of zinc on immune function. Metallomics. 2014; 6(7): 1175-1180.

https://doi.org/10.1039/c3mt00353a
16. Jayawardena R, Ranasinghe $\mathrm{P}$, Galappatthy $\mathrm{P}$, Malkanthi $\mathrm{R}$, Constantine $G$ and Katulanda P. Effect of zinc supplementation on diabetes mellitus: a systematic review and meta-analysis. Diabetology and Metabolic Syndrome. 2012; 4(1):13.

https://doi.org/10.1186/1758-5996-4-13

17. Naik SK, Ramanand SJ and Ramanand JB. Amedley correlation of serum zinc with glycemic parameters in T2DM patients. Indian J Endocrinol Metab. 2019; 23(2):188-192. https://doi.org/10.4103/ijem.IJEM_7_19

18. Jyothirmay B and Vasantha M. Study of Zinc and Glycated $\mathrm{Hb}$ Levels in Diabetic Complications.International Journal of Pharmaceutical and Clinical Research. 2015;7(5): 360-363.

19. Dasarathan R, Senthil Kumar S, Ganesh V and Chenthil KS. Study of serum Zinc status among type 2 diabetes mellitus patients: Int J Adv Med. 2017;4(5):1344-1347. https://doi.org/10.18203/2349-3933.ijam20174176

20. Sunthari $\mathrm{K}$, Chidambaram $\mathrm{N}$ and Umarani $\mathrm{R}$. Correlation of Serum Zinc and Glycated Hemoglobin (HbA1C) of Newly Diagnosed Type 2 Diabetes Mellitus Patients in a Tertiary Hospital of Chidambaram. Journal of Medical Science and Clinical Research. 2018; 06(10): 563-569. https://doi.org/10.18535/jmscr/v6i10.93

21. Pujar S, Pujar LL, Ganiger A, Hiremath K, Mannangi N and Bhuthal M. Correlation of serum zinc, magnesium and copper with $\mathrm{HbA} 1 \mathrm{c}$ in type 2 diabetes mellitus patients. Medica Innovatica. $2014 ; 3(2)$ : 4-8. https://doi.org/10.5958/2321-1032.2015.00017.0

Author's contribution:

PM-Concept and design of the study; prepared first draft of manuscript; SD - Interpreted the results; reviewed the literature and manuscript preparation;

GP- Concept, coordination, review of literature. MP and VI - Statistically analysed and interpreted, preparation of manuscript and revision of the manuscript.

Work attributed to:

Sri Venkateshwaraa Medical College Hospital and Research Centre, Puducherry, India.

Orcid ID:

Dhanoushyaa Seetharaman- (i) https://orcid.org/0000-0002-8324-0450

Prof. Muraliswaran Perumal- (D) https://orcid.org/0000-0001-9200-2617

Dr. Priyatharshini Mohan- (1) https://orcid.org/0000-0003-0137-7857

Dr. Prabu Gnanasekaran- (D) https://orcid.org/0000-0002-9958-5656

Indhumathi Venkatesan- (i) https://orcid.org/0000-0002-9958-5656

Source of Funding: Indian Council of Medical Research, 2020, Conflict of Interest: None. 